\title{
The contribution made by school milk to the nutrition of primary schoolchildren
}

\author{
By JUDITH COOK, D. G. ALTMAN, ANN JACOBY AND \\ W. W. HOLLAND \\ Department of Community Medicine, St Thomas's Hospital Medical School, \\ London $S E_{\mathrm{I}}{ }_{\mathrm{T}} E H$
}

AND A. ELLIOTT

County Medical Officer, Kent County Council

(Received 23 September 1974 - Accepted 6 January I975)

\begin{abstract}
I. The contribution of school milk to the nutrition of 396 Kent primary schoolchildren aged 8-r I years was assessed using information collected in a survey which included a weigheddiet record, a socio-economic questionnaire and a medical examination.

2. Over half the children ( $59 \%$ for boys, $54 \%$ for girls) drank school milk every school day of the diet-record week.

3. Children who drank school milk every school day, when compared with those not drinking it, had a significantly higher mean daily intake of liquid milk, a higher total daily intake of several important nutrients including animal protein, calcium, thiamin and riboflavin, and $\mathrm{a}$ diet richer in $\mathrm{Ca}$ and riboflavin (boys) and animal protein and $\mathrm{Ca}$ (girls). They were also less likely to have intakes of $\mathrm{Ca}$ and riboflavin below the recommended daily intakes for these nutrients (Department of Health and Social Security, I969).

4. The increased nutritional intake associated with school milk consumption was not related to any differences in height, weight, arm circumference or skinfold thickness.

5. There was no evidence that school milk consumption was associated with obesity (as assessed clinically).
\end{abstract}

The provision of free school milk has formed an important part of this country's food policy for many years. In 1946, as part of the 'Beveridge' family support arrangements, I90 $\mathrm{ml}$ (one-third pint) milk/d was made available, free, to all children attending school. In the autumn of 1968 the Government discontinued the supply of free milk to pupils in secondary schools. The 1971 Education (Milk) Act (Great Britain: Parliament, 1971) further reduced the provision of free school milk by limiting the supply to children up to the end of the summer term after their seventh birthday. Older children with a certified medical need would still continue to receive free milk.

There has been much debate over the implications of these changes in policy for the health and nutrition of schoolchildren. A major problem has been that there is very little objective evidence, currently relevant, with which to assess the role of school milk in the nutrition of schoolchildren. Some previous evidence has been provided by studies on the influence of supplementary feeding with milk on the growth of children. A marked gain in height and weight, and improvement in physical condition was found when children were given $568 \mathrm{ml}$ (I pint) milk/d for a period of 7 months (Corry-Mann, I926). In a similar study (Leighton \& Clark, 1929) the growth rates of boys in an institution were found to increase when they were given 
$568 \mathrm{ml} \mathrm{milk} / \mathrm{d}$ for periods of between $\mathrm{I}$ and 3 years. The increase in growth was greater for height than for weight for 6-year-old children and greater for weight than for height for I3-year-old children. The Milk Nutrition Committee (1939) found that supplementing the diet of children with $379 \mathrm{ml}$ (two-thirds pint) milk/d for a period of 1 year resulted in a small but significant improvement in their rate of increase in height.

These studies were carried out many years ago when diet and socio-economic conditions in this country were very different from today. Data from a study in Kent during $1969-70$ provided the opportunity to study the contribution of school milk to the nutrition of primary schoolchildren.

During the study period, from September 1968 to January 1970, free school milk was available to all primary schoolchildren. It had ceased to be available to secondary schoolchildren after the end of the summer term in 1968 under the Public Expenditure and Receipts Act, I 968 (Great Britain: Parliament, 1969).

\section{METHODS}

The study was designed to examine the dietary intake of schoolchildren, to study its relationship to health and socio-economic factors and to explore the extent and nature of poor nutrition.

The information obtained for each child who took part in the study was as follows: (I) a socio-economic questionnaire, which included questions on family structure, father's occupation and mother's work status, was completed under the supervision of a fieldworker; (2) a I-week weighed-diet record was made under the supervision of a fieldworker (3) a medical examination was made by one of two medical officers within 3 months of the completion of the weighed-diet record. The examination included a clinical assessment of the nutritional status of the child and measurement of height, weight, arm circumference and triceps and subscapular skinfold thicknesses.

The administration of the questionnaire and supervision of the weighed-diet record was done by health visitors, district nurses and midwives from the former Kent County Council Health Department. Fieldwork organization and the maintenance of the standard of diet recording were undertaken by two dietitians.

The sample, which included children living in four areas of Kent and attending local authority schools, was stratified on the basis of age, weight, sex, social class (using the Classification of Occupations I970 (Office of Population Censuses and Surveys, 1970)) and family size. Relatively more children from larger families, fatherless families and lower social classes were selected as they were considered to be those most at risk from poor nutrition. The total sample included children of both primary and secondary school age-groups. The study was satisfactorily completed by 396 primary schoolchildren between the ages of 8 and II years, providing diet records made both during the school term and holidays. 


\section{Dietary information collected in the study}

Information about the child's intake of school milk and the type of lunch eaten during the school term was collected in a socio-economic questionnaire. Parents were asked to categorize the child's usual intake of school milk as being: (a) every day, (b) most days, $(c)$ occasionally, $(d)$ never.

The information provided by parents about the intake of school milk will be referred to as 'reported intake'. The weighed-diet record contained information about school milk actually drunk by children during the week of diet recording. This is referred to as 'actual intake' of school milk expressed as number of $d$ on which school milk was drunk.

A I-week weighed-diet record was made using a cumulative method of weighing. All food and drink consumed by the child during the week of the diet record was weighed on a modified set of letter-balance scales and recorded in a diet-record book. The weight of food was recorded to the nearest $0.25 \mathrm{oz}(7 \cdot \mathrm{I} \mathrm{g})$, taking the lower value on the scale. A detailed description and the cumulative weight of the food items served was recorded, together with the day and time of serving and information about leftovers (Topp, Cook \& Elliott, r972). A fieldworker demonstrated the method of recording and supervised the record, making a minimum of three visits in the survey week.

A food code was allocated to each food item eaten (including cooked and made-up dishes) and the energy value and nutrient content was calculated. Food codes and nutrient conversion values were supplied by the Ministry of Health (Department of Health and Social Security: DHSS). Allowance for leftovers was made when calculating the amount of food eaten.

\section{RESULTS}

\section{School milk consumption}

The relationship between reported and actual intake of school milk was studied using data obtained from $3^{12}$ children during the school term. The frequency of school milk intake (actual intake) during the diet-record week was compared with the parents' assessment (reported intake) ('Table I). All children reported by parents as never taking school milk had taken no milk during the study week, and most of the children reported as having school milk every day had recorded drinking milk every day at school. Any discrepancies between reported and actual intake may have been in part the result of children having been absent from school for all or part of the survey week and in part to the parents' assessment being an over-estimate. In general the parents' report gave a good indication of actual intake of school milk.

For the boys $85 \%$ were reported to drink school milk every day compared with $73 \%$ for the girls, and $\mathrm{r} 8 \%$ of the girls were reported never to drink school milk compared with $6 \%$ for the boys (Table 2). Similarly, $59 \%$ of the boys studied during the school term actually drank school milk on each of the $5 \mathrm{~d}$ of the diet-record week, compared with $54 \%$ for girls (Table 2). Nearly $25 \%$ of the girls drank no school milk in the diet-record week compared with $14 \%$ for the boys.

The relationship between both actual and reported intake of school milk and mean 
'Table I. Comparison between parents' assessment of usual school milk intake (reported intake) and the frequency of school milk intake during the diet-record week (actual intake) for 312 children aged 8-1 I years studied during the school term

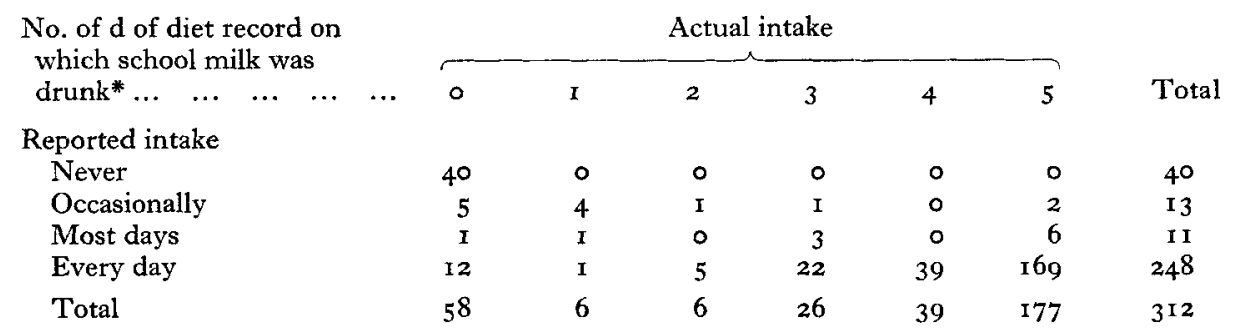

* For all children the week of the diet record included 5 school days on which $190 \mathrm{ml} \mathrm{school} \mathrm{milk/}$ child per d was provided.

Table 2. Parents' assessment of usual school milk intake during the diet-record week (reported intake) and the frequency of school milk intake (actual intake) during the dietrecord week for $3 \mathrm{I} 2$ schoolchildren aged 8-I I years studied during the school term

(Results expressed as a percentage of the total are given in parentheses)

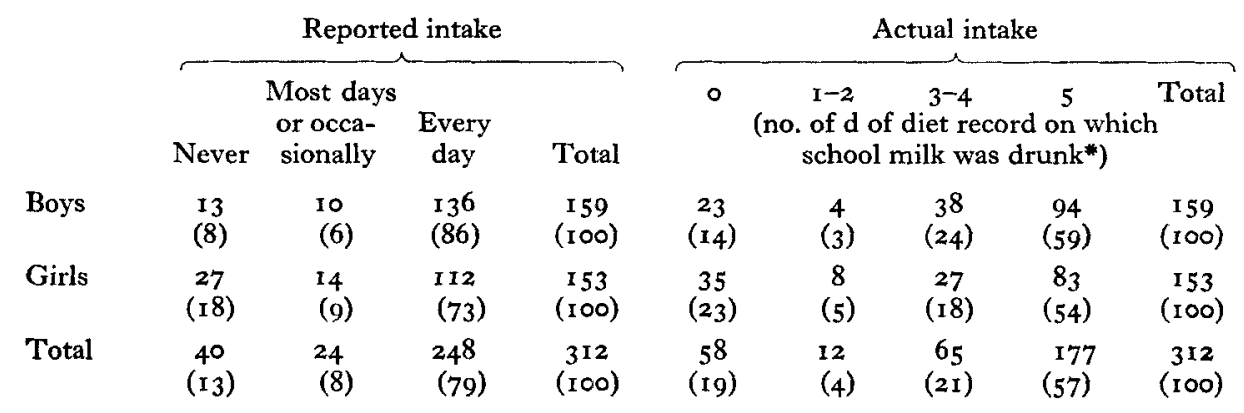

* For all children, the week of the diet record included 5 school days on which $190 \mathrm{ml}$ school milk/ child per $d$ was provided.

daily intake of liquid milk (the amount of liquid whole milk drunk as such or in tea, coffee or other drinks, excluding milk used in cooking or composite dishes) was explored. If children who did not take school milk were found to drink less milk at home this would suggest they disliked milk in general. Children taking school milk $5 \mathrm{~d} /$ week had a highly significantly greater daily intake of liquid milk than those who drank no milk at school (Table 3 ). The differences in total intake of liquid milk between those who took no milk and those who took milk at school $5 \mathrm{~d} /$ week could be almost completely accounted for by the difference in consumption at school; consumption of liquid milk at home was the same for both groups of children. However, children who drank school milk had a mean daily intake of liquid milk of nearly $500 \mathrm{ml}$ whereas children who did not take school milk drank about $300 \mathrm{ml}$ daily. School milk represented one-third of the liquid milk intake of children who drank it. These differences in liquid whole milk intake accounted for differences in total milk intake from all 
Table 3. Comparison between mean daily intake of liquid whole milk $(\mathrm{ml})$ and frequency

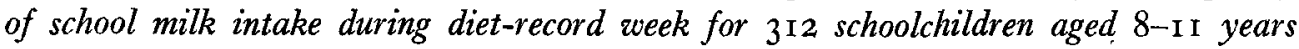
studied during the school term

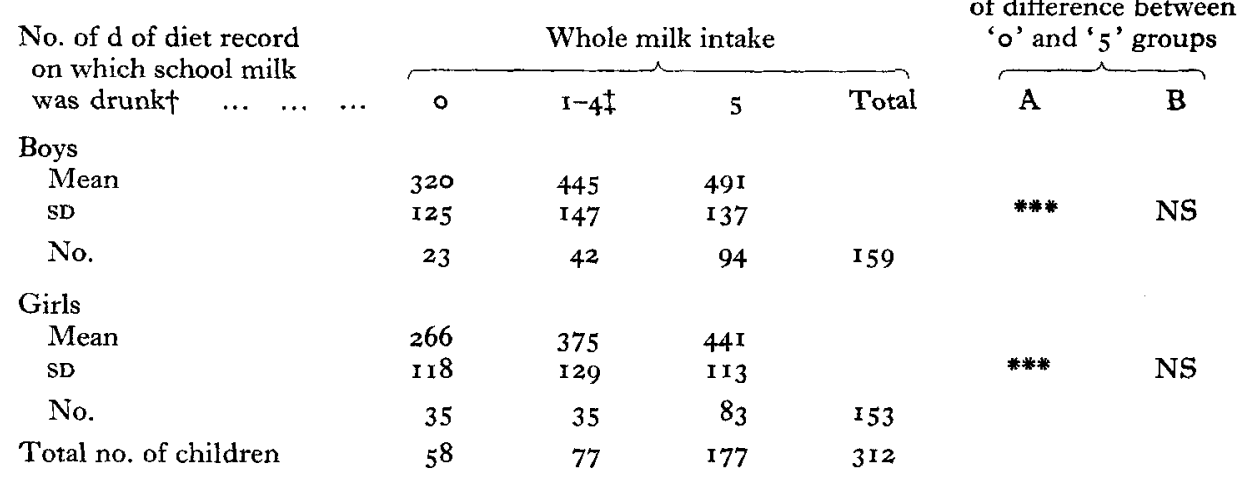

Statistical significance of difference between $\circ$ ' and ' 5 ' groups

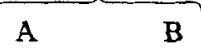

A, the difference between the intake in ' 0 ' and ' 5 ' groups; $B$, the difference found in intake between ' $O$ ' and ' 5 ' groups compared with the theoretical difference due to the intake of $190 \mathrm{ml} \mathrm{school} \mathrm{milk/d}$ for $5 \mathrm{~d} /$ week; NS, not significant.

**** $P<0.001$.

+ For all children, the week of the diet record included 5 school days on which $190 \mathrm{ml}$ school milk/ child per $\mathrm{d}$ was provided.

$\ddagger$ Mean no. of intakes, approximately 3 .

sources (including milk used in cooking, in manufactured foods and processed milk) between children who drank school milk and those who did not drink it.

\section{Socio-economic factors}

No differences in school milk intake were found between social classes or familysize groups, or groups based on the mother's working status. There were no differences in school milk intake between children living in the four areas of Kent included in the study.

\section{Nutritional status}

In the medical examination the child's nutritional status was assessed subjectively by the medical officer using predetermined criteria (including the amount of subcutaneous fatty tissue, muscle bulk and the general condition of skin and hair). Children were assessed as obese, or of good, fair or poor nutritional status. No children were considered to be of poor nutritional status. No association was found between clinical assessment and either reported or actual intake of school milk. In particular, children who drank school milk were no more likely to be assessed as obese than those who did not. There were no children in the study who showed clinical signs of vitamin deficiency.

Multiple covariance analysis was used to compare height, weight, arm circumference, and triceps and subscapular skinfold thicknesses for groups of children drinking different amounts of school milk. The covariates in the analyses were age, sex, social class and number of siblings (height was included as a covariate in the 
Table 4. Comparison of nutrient intake and frequency of school milk intake during dietrecord week for $3^{12}$ schoolchildren aged 8-1 I years studied during the school term

\begin{tabular}{|c|c|c|c|c|c|c|c|c|}
\hline \multirow{3}{*}{$\begin{array}{l}\text { No. of } d \text { of diet record } \\
\text { on which school milk } \\
\text { was drunkt } \quad \ldots \quad \ldots\end{array}$} & \multicolumn{5}{|c|}{ Nutrient intake } & \multirow{2}{*}{\multicolumn{3}{|c|}{$\begin{array}{c}\text { Statistical } \\
\text { significance of } \\
\text { difference between } \\
\text { ' } 0 \text { ' and ' } 5 \text { ' } \\
\text { intake groups }\end{array}$}} \\
\hline & \multicolumn{3}{|c|}{ Boys } & \multicolumn{2}{|r|}{ Girls } & & & \\
\hline & 0 & $I-4$ & 5 & 0 & $I-4$ & 5 & Boys & Girls \\
\hline \multicolumn{9}{|l|}{ Nutrient } \\
\hline Energy: kcal & 2135 & 2267 & 2325 & I 846 & 1902 & 2128 & & \\
\hline $\mathrm{MJ}$ & 8.93 & $9 \cdot 48$ & 973 & 7.72 & $7 \cdot 96$ & $8 \cdot 90$ & * & $* * *$ \\
\hline Animal protein (g) & $36 \cdot 2$ & $43 \cdot 7$ & $42 \cdot 8$ & $32 \cdot 5$ & $36 \cdot 4$ & $40 \cdot 6$ & $* *$ & $* * *$ \\
\hline Total protein $(\mathrm{g})$ & $57 \cdot 5$ & 66.5 & $66 \cdot 5$ & $5 I \cdot 5$ & $54 \cdot 7$ & $6 I \cdot I$ & $* *$ & $* * *$ \\
\hline Fat $(\mathrm{g})$ & $87 \cdot 1$ & $95 \cdot 3$ & 95.8 & $79^{\circ} 0$ & $81 \cdot 0$ & $90 \cdot 0$ & $*$ & ** \\
\hline Carbohydrate (g) & 297 & $3 \circ 3$ & 317 & 243 & 253 & 285 & - & $* * *$ \\
\hline Calcium (mg) & 812 & 1042 & 1083 & $7+6$ & 873 & 988 & $* * *$ & $* * *$ \\
\hline Iron (mg) & $10.6 I$ & II. 24 & I I.34 & 9.59 & 9.04 & 10.40 & 一 & - \\
\hline Retinol (mg) & 0.85 & 0.98 & I.OI & $\mathrm{I} \cdot 02$ & 0.94 & 0.95 & - & - \\
\hline Thiamin (mg) & 0.93 & $I \cdot I I$ & $I \cdot I I$ & .079 & 0.90 & 0.98 & ** & $* * *$ \\
\hline Riboflavin (mg) & $x \cdot 34$ & $\mathrm{I} \cdot 63$ & $1 \cdot 72$ & $1 \cdot 24$ & $\mathrm{I} \cdot \mathbf{4 7}$ & $\mathrm{I} \cdot 55$ & *** & $* * *$ \\
\hline Nicotinic acid $(\mathrm{mg})$ & II $\cdot 2$ & 12.4 & $12 \cdot 0$ & $9 \cdot 35$ & 10.0 & $10 \cdot 3$ & - & - \\
\hline Ascorbic acid (mg) & $47 \cdot 0$ & 60.9 & $45^{\circ} 9$ & $39 \cdot 1$ & $41 \cdot 3$ & $49 \cdot 2$ & - & $*$ \\
\hline Cholecalciferol $(\mu \mathrm{g})$ & $1 \cdot 75$ & $2 \cdot 98$ & $2 \cdot 74$ & $I \cdot 92$ & $2 \cdot 33$ & 3.07 & - & - \\
\hline Pyridoxine (mg) & $1 \cdot 09$ & $I \cdot 22$ & $r \cdot r 9$ & 0.94 & 0.04 & $1 \cdot 14$ & - & $* * *$ \\
\hline No. of children & 23 & 42 & 94 & 35 & 35 & 83 & & \\
\hline
\end{tabular}

analysis of weight). No association was found between either reported or actual school milk intake and any of the variables.

\section{Nutrient intake}

The average daily nutrient intake of the children drinking different amounts of school milk during the diet-record week was compared (Table 4). For children of both sexes, intake of nearly all nutrients was higher for those children drinking school milk every day (five intakes) than for those not drinking it at all (no intakes), and the differences were more often statistically significant for the girls than for the boys. The important nutrients supplied by milk are animal protein, $\mathrm{Ca}$ and riboflavin, and there were highly significant differences between boys and girls for the intake of these nutrients.

School milk ( $190 \mathrm{ml}$ ) supplies: $0.544 \mathrm{MJ}$ ( $130 \mathrm{kcal})$ energy, $6 \mathrm{~g}$ protein, $230 \mathrm{mg} \mathrm{Ca}$ and $0.25 \mathrm{mg}$ riboflavin. The differences in nutrient intake between children in the ' $O$ ' (school milk never drunk) and ' 5 ' (school milk drunk on 5 school days) intake groups were compared with the theoretical increase in intake of nutrients which would result from drinking $190 \mathrm{ml}$ milk on each school day (Table 5 ). For nearly all nutrients the values obtained for these differences were greater than the theoretical values for these differences. However, there was large variation between individuals for the intake of nutrients, therefore, few of the differences between the values obtained and 
Table 5. Actual and theoretical differences in average daily nutrient intake during the diet-record week between ' $O$ ' and ' 5 ' school milk intake groups $\uparrow$ for 312 schoolchildren aged 8-I I years studied during the school term

\begin{tabular}{|c|c|c|c|c|c|}
\hline \multirow[b]{2}{*}{ Nutrient } & \multicolumn{2}{|c|}{ Actual difference } & \multirow{2}{*}{$\begin{array}{l}\text { Theoretical } \\
\text { differencef }\end{array}$} & \multicolumn{2}{|c|}{$\begin{array}{l}\text { difference between actua } \\
\text { and theoretical values }\end{array}$} \\
\hline & Boys & Girls & & Boys & Girls \\
\hline Energy: kcal & I90 & 282 & $90 \cdot 5$ & - & $*$ \\
\hline $\mathrm{MJ}$ & 0.79 & $1 \cdot 18$ & 0.38 & - & $*$ \\
\hline Animal protein (g) & $6 \cdot 56$ & $8 \cdot 16$ & $4^{\cdot 29}$ & - & - \\
\hline Total protein (g) & $9 \cdot 03$ & 9.57 & $4 \cdot 29$ & 一 & $*$ \\
\hline Fat $(g)$ & $8 \cdot 63$ & $11 \cdot 0$ & $5^{24}$ & - & - \\
\hline Carbohydrate (g) & $19 \cdot 8$ & $3^{8 \cdot 2}$ & 6.7 & - & - \\
\hline Calcium (mg) & 271 & 245 & 162 & $*$ & - \\
\hline Iron (mg) & 0.73 & $0.8 I$ & 0.10 & - & - \\
\hline Retinol (mg) & 0.16 & -0.06 & 0.05 & - & - \\
\hline Thiamin (mg) & 0.18 & $0 \cdot 19$ & 0.05 & - & $*$ \\
\hline Riboflavin (mg) & 0.38 & 0.30 & 0.18 & - & - \\
\hline Nicotinic acid (mg) & 0.75 & 0.91 & 0.10 & 一 & - \\
\hline Ascorbic acid (mg) & -1.09 & $10 \cdot 2$ & $I \cdot 43$ & - & - \\
\hline Cholecalciferol $(\mu \mathrm{g})$ & 0.99 & $1 \cdot 15$ & 0.04 & 一 & - \\
\hline Pyridoxine (mg) & 0.09 & 0.21 & 0.05 & - & ** \\
\hline
\end{tabular}

Table 6. Comparison of nutrient intake $\left(/ 4 \cdot{ }^{1} 84 M Y(1000 \mathrm{kcal})\right)$ and frequency of school milk intake during the diet-record week for $3 \mathrm{I} 2$ schoolchildren aged 8-1 I years studied during the school term

\begin{tabular}{|c|c|c|c|c|c|c|c|c|}
\hline \multirow{2}{*}{$\begin{array}{l}\text { No. of } d \text { of diet-record } \\
\text { on which school milk }\end{array}$} & \multicolumn{6}{|c|}{ Nutrient intake } & \multirow{2}{*}{\multicolumn{2}{|c|}{$\begin{array}{c}\text { significance of } \\
\text { difference between } \\
\text { ' } 0 \text { ' and ' } 5 \text { ' } \\
\text { intake groups }\end{array}$}} \\
\hline & \multicolumn{3}{|c|}{ Boys } & \multicolumn{3}{|c|}{ Girls } & & \\
\hline $\begin{array}{l}\text { on which school milk } \\
\text { was drunkt } \quad \ldots\end{array}$ & $\ldots$ & $I-4$ & 5 & 0 & $x-4$ & 5 & Boys & Girls \\
\hline \multicolumn{9}{|l|}{ Nutrient } \\
\hline Animal protein $(\mathrm{g})$ & $17 \cdot 2$ & $19 \cdot 3$ & $18 \cdot 5$ & $17 \cdot 3$ & $19 \cdot 2$ & $19 \cdot 2$ & - & $*$ \\
\hline Total protein $(\mathrm{g})$ & $27 \cdot 1$ & 29.4 & $28 \cdot 7$ & $27 \cdot 7$ & $28 \cdot 9$ & $28 \cdot 8$ & $*$ & - \\
\hline Fat $(\mathrm{g})$ & 40.8 & $4 \times 9$ & $4 I \cdot I$ & $42 \cdot 5$ & $42 \cdot 4$ & $42 \cdot 3$ & - & - \\
\hline $\begin{array}{l}\text { Carbohydrate (g) } \\
\text { Calcium (mg) }\end{array}$ & $\begin{array}{l}139 \\
385\end{array}$ & $\begin{array}{l}134 \\
458\end{array}$ & $\begin{array}{l}136 \\
468\end{array}$ & $\begin{array}{l}134 \\
400\end{array}$ & $\begin{array}{l}133 \\
461\end{array}$ & $\begin{array}{l}134 \\
467\end{array}$ & $\bar{*}$ & $\overline{* * *}$ \\
\hline Iron (mg) & $\frac{5.00}{305}$ & $\begin{array}{r}45^{\circ} \\
5.01\end{array}$ & $\begin{array}{r}400 \\
4.87\end{array}$ & $\begin{array}{r}400 \\
5 \cdot 19\end{array}$ & $\begin{array}{r}401 \\
4 \div 79\end{array}$ & $\begin{array}{r}407 \\
4.88\end{array}$ & - & - \\
\hline Retinol (mg) & 0.40 & 0.43 & 0.43 & 0.54 & 0.51 & 0.45 & 一 & - \\
\hline Thiamin (mg) & 0.43 & 0.49 & 0.48 & 0.43 & 0.47 & 0.46 & $*$ & - \\
\hline Riboflavin (mg) & 0.63 & 0.72 & 0.74 & 0.67 & 0.77 & 0.73 & $* *$ & - \\
\hline Nicotinic acid (mg) & $5 \cdot 20$ & $5 \cdot 47$ & $5 \cdot 16$ & $5 \cdot 11$ & $5 \cdot 27$ & $4 \cdot 84$ & - & - \\
\hline Ascorbic acid (mg) & $22 \cdot 9$ & $27 \times 0$ & $19 \cdot 7$ & $2 x \cdot 0$ & $21 \cdot 6$ & $23 \cdot 2$ & - & - \\
\hline Cholecalciferol $(\mu \mathrm{g})$ & 0.83 & $1 \cdot 25$ & $I \cdot 16$ & $\mathrm{I} \cdot 04$ & I'2I & $\mathrm{I} \cdot 45$ & - & - \\
\hline Pyridoxine (mg) & 0.52 & 0.55 & $0.5 \mathrm{I}$ & 0.51 & 0.55 & 0.54 & - & - \\
\hline No. of children & 23 & 42 & 94 & 35 & 35 & 83 & & \\
\hline
\end{tabular}

* $P<0.05$, * $P<0.01$, *** $P<0.001$.

+ For all children, the week of the diet-record included 5 school days on which $190 \mathrm{ml}$ school milk/ child per $\mathbf{d}$ was provided. 
theoretical values were statistically significant. The differences obtained were large, and nutrient intake was consistently greater for children drinking school milk every day. However, only for pyridoxine intake for girls was there a much larger difference between the ' $O$ ' and ' 5 ' intake groups than would be accounted for by drinking school milk.

For children of both sexes there was a significant difference in energy intake between the ' 0 ' and ' 5 ' intake groups. To study the influence of school milk intake on the quality of the diet it was necessary to examine the nutrient intakes on an energy intake basis $(/ 4 \cdot 184 \mathrm{MJ}$ (1000 kcal)) for the different milk-intake groups. Mean daily nutrient intakes $/ 4 \cdot 184 \mathrm{MJ}$ (1000 kcal) were compared for the ' 0 ' and ' 5 ' intake groups. In general, the differences were not statistically significant (Table 6). However there were highly significant differences, on an energy intake basis, between the groups drinking school milk for $\mathrm{Ca}$ and riboflavin intake for boys, and for $\mathrm{Ca}$ intake for girls.

\section{DHSS recommended intakes of nutrients}

The intake of calcium and riboflavin for the children in the study was compared with the recommended levels of daily intake (Department of Health and Social Security, 1969). Children were divided into groups according to whether their intakes of calcium and riboflavin were above or below the recommended levels for their age and sex. The intake of one or both nutrients was below these levels for $28 \%$ of the children (Table 7). A significantly greater number of children studied during school holidays $(49 \%)$ had intakes below the recommended levels for one or both nutrients compared with those studied during school term $(22 \%)$. Children from larger families were significantly more likely to have intakes below these levels. Twice as many children from social classes III $b$, IV and V had intakes below recommended levels for one or both nutrients, than those from social classes I II, and III $a$, but this difference was not statistically significant. Also fewer children from fatherless families had intakes below the recommended levels, but this difference was not statistically significant. Children who drank no school milk were significantly more likely to have intakes below the recommended levels for $\mathrm{Ca}$ and riboflavin than children who drank school milk every day (Table 8).

The height of the children in the groups with intakes of $\mathrm{Ca}$ and riboflavin above or below the DHSS recommended levels was compared, using multiple covariance analysis, and using age, sex, social class and number of siblings as covariates. Significant differences in adjusted height were found; children with intakes above the recommended levels for both $\mathrm{Ca}$ and riboflavin were on average $0.038 \mathrm{~m}$ taller than children whose intakes for both nutrients were below the recommended levels $(P<$ 0.01 ). Children whose intake of only one nutrient was below recommended levels had adjusted heights between those of the other two groups (intakes of both $\mathrm{Ca}$ and riboflavin above or below recommended levels). As children drinking school milk were more likely to have intakes of $\mathrm{Ca}$ and riboflavin above the recommended levels (Table 8) the analysis was repeated using school milk as an added covariate. The differences in height were of the same order and of the same statistical significance. However, as the intake of $\mathrm{Ca}$ and riboflavin is correlated with total intake of food 
Vol. 34

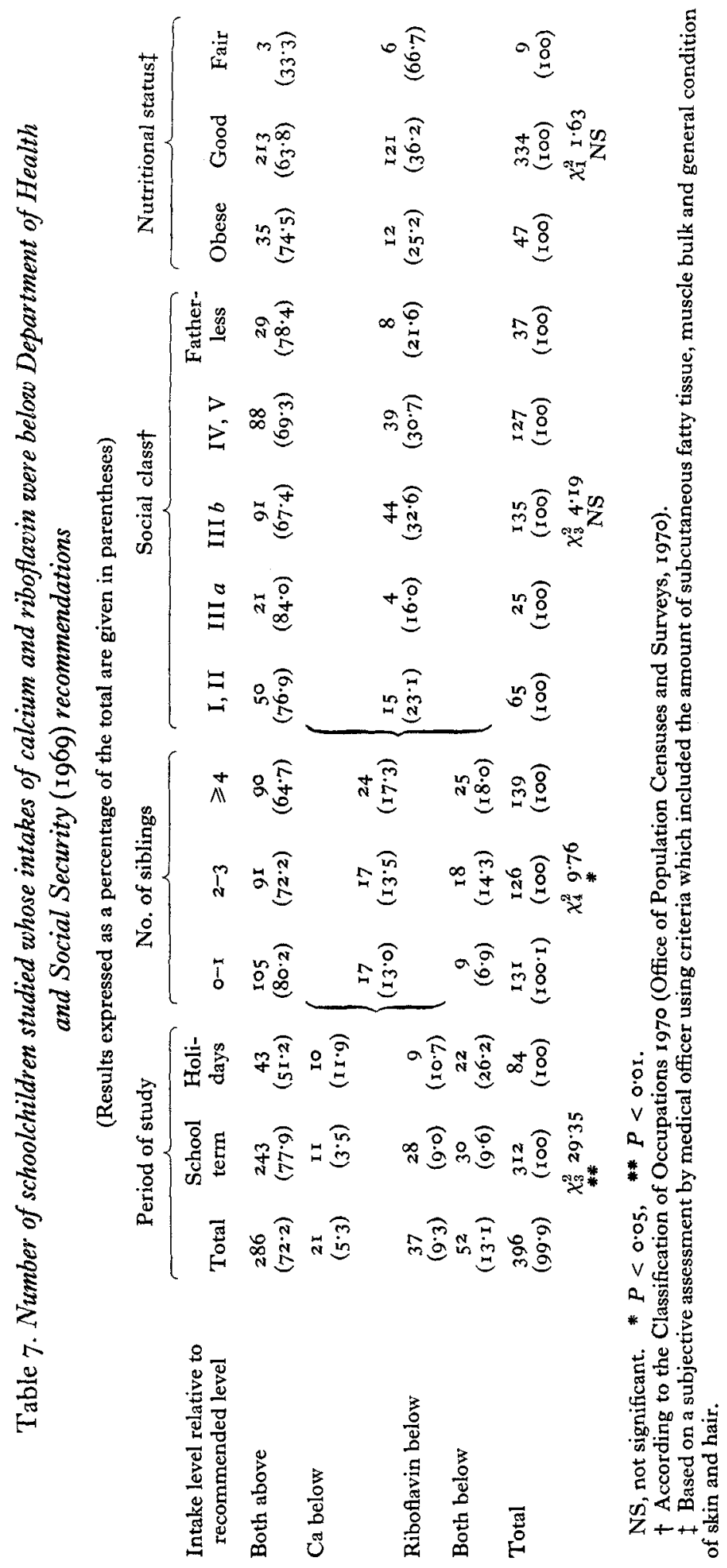


Table 8. Comparison between number of schoolchildren studied during the school term whose intakes of Ca and riboflavin were below Department of Health and Social Security (1969) recommendations, and school milk intake during the diet-record week

(Results expressed as a percentage of the total are given in parentheses)

\begin{tabular}{|c|c|c|c|c|}
\hline \multirow{2}{*}{ 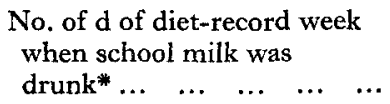 } & \multicolumn{4}{|c|}{ School milk intake } \\
\hline & o & $1-4$ & 5 & Total \\
\hline \multicolumn{5}{|l|}{$\begin{array}{l}\text { Intake level relative to } \\
\text { recommended level }\end{array}$} \\
\hline Both above & $\begin{array}{c}27 \\
(47)\end{array}$ & $\begin{array}{c}59 \\
(77)\end{array}$ & $\begin{array}{l}157 \\
(89)\end{array}$ & $\begin{array}{c}243 \\
(78)\end{array}$ \\
\hline $\mathrm{Ca}$ or riboflavin below & $\begin{array}{c}14 \\
(24)\end{array}$ & $\begin{array}{l}12 \\
(16)\end{array}$ & $\begin{array}{l}13 \\
(7)\end{array}$ & $\begin{array}{c}39 \\
(13)\end{array}$ \\
\hline Both below & $\begin{array}{l}17 \\
(29)\end{array}$ & $\begin{array}{c}6 \\
(8)\end{array}$ & $\begin{array}{c}7 \\
(4)\end{array}$ & $\begin{array}{l}3 \circ \\
\text { (10) }\end{array}$ \\
\hline Total & $\begin{array}{c}58 \\
(100)\end{array}$ & $\begin{array}{c}77 \\
(\mathrm{I} O \mathrm{I})\end{array}$ & $\begin{array}{c}177 \\
(100)\end{array}$ & $\begin{array}{l}312 \\
(101)\end{array}$ \\
\hline
\end{tabular}

* For all children, the week of the diet record included 5 school days on which r $90 \mathrm{ml}$ school milk/ child per d was provided.

the previous analysis was repeated using energy intake as another covariate. The difference in adjusted height between children with intakes of both nutrients above recommended levels and those with intakes below these levels was $0.013 \mathrm{~m}$, and was not statistically significant. A similar analysis of weight (with height as an additional covariate) showed no significant difference between the intake groups. Clinically assessed nutritional status did not differ between the groups with intakes of $\mathrm{Ca}$ and riboflavin above or below recommended levels.

\section{DISCUSSION}

The value obtained for boys and girls reported by their parents to drink school milk every day $(79 \%)$ was lower than that of $93 \%$ reported for school milk intake in 1960, for primary schoolchildren (National Dairy Council, 1961) and that of $92 \%$ for Kent primary, special and nursery schoolchildren reported as receiving school milk in 1969 (Department of Education and Science, 1970 ). Of the total, $57 \%$ of the children actually drank school milk every day and $84 \%$ drank it on most days of the diet-record week. These values for actual intake were also lower than those mentioned previously, and this may be because the earlier estimates did not allow for wastage of milk not actually drunk.

It has been shown that the way school milk is served can influence uptake (National Dairy Council, 1961). Unfortunately no information was available on why children in the study chose not to drink school milk. They may have disliked milk in general, disliked it as served at school, or eaten sweets or snacks instead (some schools in the study had tuckshops). Children in the study who drank school milk were not found to drink more milk at home or elsewhere, perhaps indicating that children failed to drink milk at school for reasons other than a general dislike of milk. 
Children who drank school milk every day had a mean total daily intake of liquid milk of nearly $500 \mathrm{ml}$ compared with a mean daily intake of about $300 \mathrm{ml}$ for children not drinking school milk. The higher liquid milk intake for children drinking school milk was accounted for solely by their consumption of school milk. For children who drank it, school milk made up about one-third of their total liquid milk intake and formed a sizeable supplement to their diet. Similar results, showing that the consumption of school milk was not associated with a higher intake of milk from other sources, have been found in a recent study of primary schoolchildren made by the DHSS (personal communication). There was no indication of selectivity in school milk consumption: there were no differences in consumption on the basis of social class, family size or mother's work status.

Milk is an almost complete food, containing a variety of essential nutrients. In particular it is the most important single contributor of $\mathrm{Ca}$ and riboflavin to the British diet (National Food Survey Committee, 1973). It thus forms a valuable and important source of some nutrients required for the growth of children. The drinking of school milk was associated with a statistically significant higher total intake of energy and many nutrients and with a higher intake $(/ 4 \cdot 184 \mathrm{MJ}$ (1000 kcal)) of animal protein and $\mathrm{Ca}$ for girls and of $\mathrm{Ca}$ and riboflavin for boys. This difference in the quality of the diet indicated a difference in the pattern of foods eaten, of which milk may not be the only food involved. Children reported to drink school milk every day were also found to be more likely to eat school meals (Cook, Altman, Jacoby, Holland \& Elliott, 1975). The school meal may be a source of variation in average daily nutrient intake, in addition to the consumption of school milk.

Although children who drank school milk had a significantly higher intake of energy (about $\mathrm{I} .004 \mathrm{MJ}(240 \mathrm{kcal}$ )), $\mathrm{Ca}$ (about $260 \mathrm{mg}$ ) and animal protein (about $7 \mathrm{~g}$ ), there was no association between height, weight, arm circumference or skinfold thickness, and the drinking of school milk. The following points need to be considered in interpretation of this lack of association. Children's dietary habits change as they grow older, and height and weight at the time of study will depend in part on the children's past environment, in which dietary intake is one factor. The children's present dietary intake may be a less important factor than the cumulative influence of their past dietary intake for children of this age. Alternatively, it may be that the extra energy intake of children drinking school milk was utilized through their having a higher resting metabolic rate or increased energy expenditure in physical activity than those children not drinking school milk. There was no evidence to support the opinion that obesity in schoolchildren was related to the consumption of school milk. Children drinking school milk were no more likely to be assessed as obese than those who did not.

The mean daily intake of $\mathrm{Ca}$ and animal protein for children in this study was above the DHSS recommended levels for these nutrients (Cook, Altman, Moore, Topp, Holland \& Elliott, r973). The lack of association between school milk intake and body size may reflect a lack of influence on growth of increased intake of these nutrients above an optimum level, for this age group. In addition, it is not known whether increased height is related to better health in children. Unfortunately no data were 
available to compare the incidence of disease among children in the study with their school milk consumption.

In the absence of differences in height, weight and nutritional status, and the lack of information on health status relative to school milk consumption, it is difficult to assess the importance of the variations found in nutrient intake. It may be helpful to relate the quality of the diet of children studied to the DHSS recommended levels of nutrient intake. The intakes for one-quarter of the children were below the DHSS recommended levels for $\mathrm{Ca}$ or riboflavin or both. More children from larger families and lower social classes had intakes below the DHSS recommended levels, in accordance with their previously reported lower intake of nutrients (Cook et al. 1973). Twice as many children were found to have intakes below these levels during school holidays than in school term, indicating a difference in food habits in which the consumption of school milk and meals during the school term was likely to be an important factor. 'The children's intakes were less likely to be below the DHSS recommended levels for $\mathrm{Ca}$ and riboflavin if they drank school milk.

Children with lower than recommended intakes of $\mathrm{Ca}$ and riboflavin were shorter. It may be that children who are shorter, within a group of the same age and sex, have lower requirements for energy and all nutrients than children who are taller. In this study differences in height between those with intakes above and below the DHSS recommended levels for $\mathrm{Ca}$ and riboflavin were not statistically significant when total energy intake was allowed for. It seems likely that the association between the children's level of intake for $\mathrm{Ca}$ and riboflavin and their height is a reflexion of their lower food requirements at the time of the study. Whether the lower stature at this time, for children who had $\mathrm{Ca}$ and riboflavin intake below DHSS recommended levels, was a result of a retardation of growth associated with a previous lower nutrient intake, could not be assessed from this study. However the nutritional status of children who had intakes of $\mathrm{Ca}$ and riboflavin below the DHSS recommended levels was no worse than that of children with intakes above these levels.

It should be stressed that the study was carried out in an area of Britain where consumption of protein-rich foods, including liquid milk, and of important nutrients supplied by milk (riboflavin and animal protein) were above the national average (National Food Survey Committee, 1973). However, the study sample contained proportionally more children from groups considered to be at risk from poor nutrition. In addition, food prices and economic conditions have changed considerably since the information was collected.

\section{Conclusions}

School milk made an important contribution to the nutritional intake of primary schoolchildren in this study. For children who drank it school milk amounted to onethird of their total liquid milk intake. School milk consumption was associated with an improvement in the quality of the diet, in particular for the nutrients $\mathrm{Ca}$ and riboflavin which are important in growth. A large number of children in the study had intakes below the DHSS recommended levels for $\mathrm{Ca}$ and riboflavin. This applied particularly to children with diet records completed during school holidays and to 
those from large families. School milk intake and an adequate level of $\mathrm{Ca}$ and riboflavin intake were found to be related. However, children showed no differences in height, weight, arm circumference or skinfold thickness which were associated with school milk intake. There was no increased prevalence of obesity (as assessed clinically) among children drinking school milk.

This work was carried out in collaboration with Kent County Council and the Department of Health and Social Security and has been supported in part by a grant from the Department of Health and Social Security. We thank the health and education service staff of Kent County Council particularly the health visitors, district nurses and midwives who carried out the field survey work; Mrs A. Melton and Mrs B. Winstanley who supervised the diet recording and completion of the socio-economic questionnaires; Dr W. T. C. Berry, Mrs M. Disselduff and Dr S. J. Darke at the Department of Health and Social Security for their advice and guidance; Dr S. J. Darke for carrying out a proportion of the medical examinations; Mrs J. Swan, Mrs S. Trew and Marti Parker for their work on the analysis. The data were analysed using the University of London CDC 660o. We wish to thank also the families and children who worked so hard on the diet recording.

\section{REFERENCES}

Cook, J., Altman, D. G., Jacoby, A., Holland, W. W. \& Elliott, A. (I975). Br. J. prev. soc. Med. (In the Press.)

Cook, J., Altman, D. G., Moore, D. M. C., Topp, S. G., Holland, W. W. \& Elliott, A. (1973). Br. F. prev. soc. Med. 27, 9x.

Corry-Mann, H. C. (1926). Spec. Rep. Ser. med. Res. Coun. no. 105.

Department of Education and Science (I970). School Meals and Milk. Autumn Return 1969. London: Department of Education and Science.

Department of Health and Social Security (1969). Rep. publ. Hlth med. Subj., Lond. no. I20.

Great Britain: Parliament (1 969). Stat. Instrum. no. 483 .

Great Britain: Parliament (1971). Stat. Instrum. no. 1368.

Leighton, G. \& Clark, M. L. (I929). Lancet i, 40.

Milk Nutrition Committee (1939). Milk and Nutrition, part 4. Reading: National Institute for Research in Dairying.

National Dairy Council (1961). National Dairy Council Information Booklet, no. 2. London: National Dairy Council.

National Food Survey Committee (1973). Household Food Consumption and Expenditure: 1970 and 1971. A report of the National Food Survey Committee, Ministry of Agriculture, Fisheries and Food. London: H.M. Stationery Office.

Office of Population Censuses and Surveys (1970). Classification of Occupations 1970. Office of Population Censuses and Surveys. London: H.M. Stationery Office.

Topp, S. G., Cook, J.\& Elliott, A. (1972), Br.F.prev. soc. Med. 26, ro6. 